\title{
2. LEG SYNTHESIS: SEA-LEVEL CHANGES AND FLUID FLOW ON THE GREAT BAHAMA BANK SLOPE ${ }^{1}$
}

\author{
Shipboard Scientific Party ${ }^{2}$
}

\section{INTRODUCTION}

During Ocean Drilling Program Leg 166 we drilled 17 holes at seven sites (Sites 1003-1009) on the western flank of the Great Bahama Bank (GBB), recovering almost $3 \mathrm{~km}$ of core and $3.1 \mathrm{~km}$ of wireline logs ranging in age from late Oligocene to Holocene (Figs. 1,2). Five sites in the Straits of Florida (Sites 1003-1007) complete a transect through prograding carbonate sequences, the Bahamas Transect. Two boreholes (Clino and Unda) drilled previously on the western Great Bahama Bank as part of the Bahamas Drilling Project represent the shallow-water sites of the transect (Figs. 1, 2; Eberli et al., this volume).

Leg 166 (Bahamas Transect) had two primary objectives. The first objective was threefold: (1) to document the sedimentary record of the Neogene-Holocene sea-level changes; (2) to determine the ages of the major unconformities in the sedimentary record; and (3) to compare the sedimentary record with the oxygen isotopic record of glacio-eustasy. Facies variations of the core borings from the complete transect were expected to document that these variations are associated with oscillations of sea level, and thereby providing the sedimentary response of the carbonate environment to sea-level changes. Biostratigraphy was used aboard ship to date unconformities that are thought to be generated by sea-level changes. The correlation between the two independent records of sea-level changes, seismic sequence stratigraphy, and the oxygen isotopic proxy, can potentially help to evaluate rate and amplitude of eustatic vs. relative sea-level changes and to establish a causal link between glacio-eustasy and the stratigraphic pattern.

The second objective was to investigate the significance of fluid flow within the Great Bahama Bank. To achieve this goal, the sites of the Bahamas Transect were complemented by three additional shallow holes on the upper slope: Sites 1004, 1008, and 1009 (Fig. 1). The nature and mechanisms of fluid flow through the carbonate bank were quantified through in situ temperature measurements and through analyses of the composition of the interstitial fluids retained in the sediment.

We present in the back-pocket foldout a compilation of the data over the Bahamas Transect (Sites 1003-1007), including the highresolution multichannel seismic section, and the lithostratigraphic, biostratigraphic, and petrophysical data that compose the basic data set for the interpretation of the sequence stratigraphic architecture of the Great Bahama Bank margin.

\section{SEA-LEVEL CHANGES}

With the sedimentary sequence recovered with advanced hydraulic piston coring, extended core barrel, and rotary core barrel drilling

${ }^{1}$ Eberli, G.P., Swart, P.K., Malone, M.J., et al., 1997. Proc. ODP, Init. Repts., 166: College Station, TX (Ocean Drilling Program).

${ }^{2}$ Shipboard Scientific Party is given in the list preceding the Table of Contents. and the abundance of biostratigraphic markers (Table 1), it was possible to define the ages of the Neogene sequence boundaries and to test their age consistency in the transect sites and to the boreholes previously drilled on the platform (Figs. 3, 4, and back-pocket foldout). By reaching the Oligocene at Site 1007, a sedimentary record of the sea-level changes is available for the entire Neogene. At all five transect sites (Sites 1003, 1004, 1005, 1006, and 1007), sedimentation rates (Fig. 5) alternate between high (up to 15 to $20 \mathrm{~cm} / \mathrm{k} . \mathrm{y}$.) and low ( $<2 \mathrm{~cm} / \mathrm{k}$.y.) values, reflecting a long-term pattern of (1) bank flooding (0.5-2 m.y.) with increased off-bank shedding of platformderived deposits on the slope and basin, and (2) concomitant exposure of the banks resulting in a shutdown of shallow-water carbonate production, and largely pelagic sedimentation. The pulses of bankderived material coincide with the prograding pulses seen in the seismic data as sequences. The geometries of these seismic sequences indicate base-level lowerings as a result of sea-level falls (Fig. 6). Within these long-term changes, high-frequency sea-level changes are recorded in decimeter-scale depositional cycles.

Facies and diagenesis act in concert to produce petrophysical differences within the sedimentary section. Thus, log data closely image

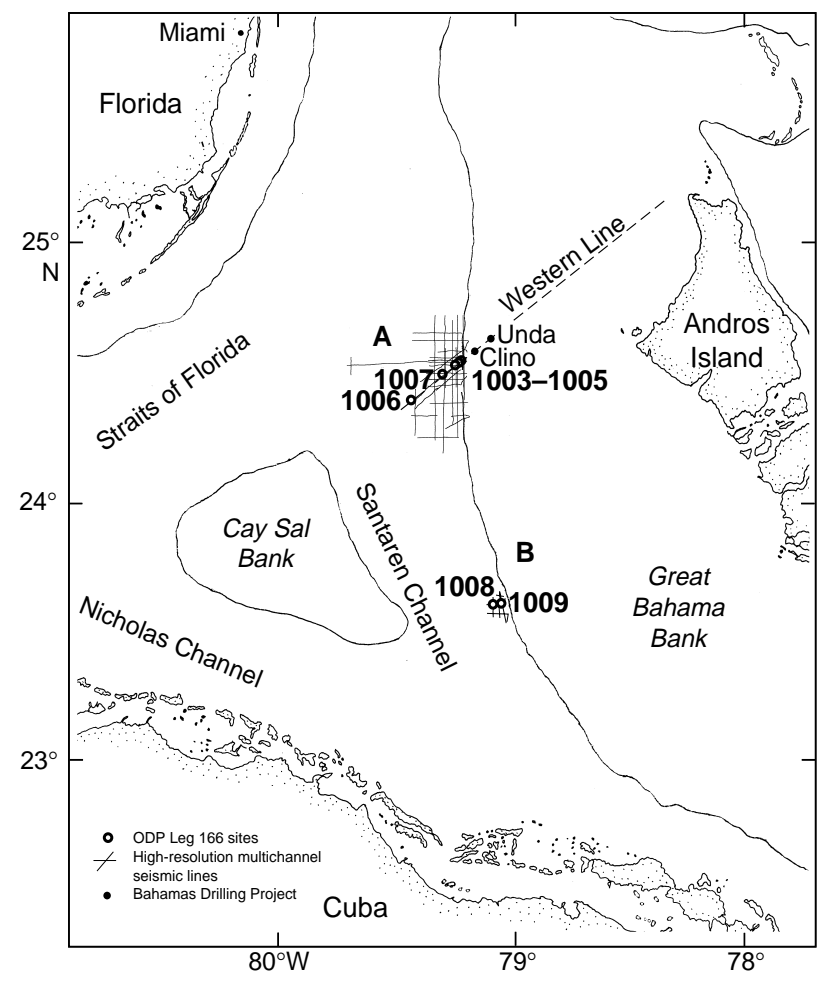

Figure 1. Location map of the Bahamas showing Leg 166 site-survey lines. Sites 1003 through 1007 are located in area A. Sites 1008 and 1009 are located in area B. 
Figure 2. Cross section through the Great Bahama Bank displaying the complicated internal architecture of the bank. Two nuclear banks, Andros and Bimini, coalesced by the infilling of an intraplatform seaway, the Straits of Andros. Progradation of the western margin of the platform during the Neogene expanded the bank more than $25 \mathrm{~km}$ into the Straits of Florida (modified from Eberli et al., 1994). The Bahamas Transect comprises Sites 1003-1007 drilled during ODP Leg 166 and boreholes Clino and Unda drilled as part of the Bahamas Drilling Project (Eberli et al., this volume).

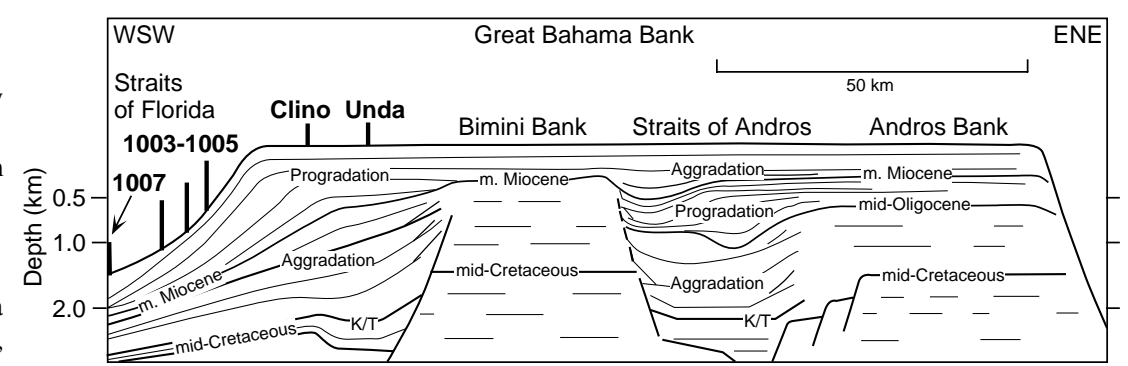

Table 1. Selected calcareous nannofossils and planktonic foraminifer datums.

\begin{tabular}{|c|c|c|c|c|c|c|c|}
\hline Event & $\begin{array}{c}\text { Nannofossil } \\
\text { age } \\
\text { (Ma) }\end{array}$ & $\begin{array}{c}\text { Foraminifer } \\
\text { age } \\
\text { (Ma) }\end{array}$ & $\begin{array}{l}\text { Site } 1006 \\
\text { depth } \\
\text { (mbsf) }\end{array}$ & $\begin{array}{l}\text { Site } 1007 \\
\text { depth } \\
\text { (mbsf) }\end{array}$ & $\begin{array}{l}\text { Site } 1003 \\
\text { depth } \\
\text { (mbsf) }\end{array}$ & $\begin{array}{l}\text { Site } 1004 \\
\text { depth } \\
(\mathrm{mbsf})\end{array}$ & $\begin{array}{c}\text { Site } 1005 \\
\text { depth } \\
\text { (mbsf) }\end{array}$ \\
\hline B E. huxleyi & 0.25 & & 4.24 & & 14.14 & 19.43 & 20.49 \\
\hline T P. lacunosa & 0.41 & & 20.53 & & 57.23 & 38.56 & 69.6 \\
\hline T R. asanoi & 0.85 & & 39.53 & & 86.46 & 81.16 & 126.56 \\
\hline T Gephyrocapsa spp. (lg) & 1.2 & & 48.49 & 14.23 & 96.98 & & 172.74 \\
\hline B Gephyrocapsa spp. (lg) & 1.44 & & 68.03 & 31.67 & & & 182.88 \\
\hline B G. caribbeanica & 1.72 & & 91.78 & 43.54 & 113.19 & 152.03 & 190.49 \\
\hline B G. truncatulinoides & & 2 & 97.69 & 53.54 & 123.75 & & \\
\hline T G. limbata & & 2.4 & 135.36 & 53.54 & 132.70 & 186.41 & \\
\hline T D. altispira & & 3.1 & 145.22 & 200.34 & 142.90 & & 226.72 \\
\hline T R. pseudoumbilica & 3.6 & & 172.53 & 200.34 & 155.79 & & 247.52 \\
\hline T G. nepenthes & & 4.2 & 240.28 & 200.34 & 197.98 & & 274.1 \\
\hline B Ceratolithus rugosus & 4.7 & & 325.98 & 287.61 & & & 365 \\
\hline T D. quinqueramus & 5.6 & & 383.42 & & & & \\
\hline T Reticulofenestra spp. (sm) & 6.5 & & 417.8 & 304.30 & & & 415.98 \\
\hline B G.conglobatus & & 6.8 & 436.04 & 327.87 & 355.61 & & 415.98 \\
\hline B G. cibaoensis & & 7.7 & 483.07 & 327.87 & 355.61 & & 415.98 \\
\hline B G. extremus & & 8.1 & 492.05 & 327.87 & 355.61 & & 415.98 \\
\hline T D. neohamatus & 8.7 & & 500.95 & 327.99 & 359.01 & & 415.98 \\
\hline T D. hamatus & 9.4 & & 530.48 & 432.99 & 488.75 & & 495.28 \\
\hline B D. hamatus & 10.7 & & 567.45 & 481.68 & 531.60 & & 582.355 \\
\hline B C. coalitus & 11.3 & & 602.51 & 503.69 & 555.10 & & 595.78 \\
\hline T G. mayeri & & 11.4 & 595.39 & 481.69 & 561.04 & & 595.78 \\
\hline B G. nepenthes & & 11.8 & 625.08 & 532.75 & 630.52 & & 651.82 \\
\hline T Fohsella spp. & & 11.9 & 639.96 & 542.48 & 641.30 & & 670.90 \\
\hline B F. fohsi & & 12.7 & 682.02 & 742.12 & 802.55 & & \\
\hline T C. floridanus & 13.2 & & 696.27 & 769.40 & 780.00 & & \\
\hline T S. heteromorphus & 13.6 & & & 780.59 & 856.84 & & \\
\hline B $F$. praefoshi & & 14 & & 791.54 & 910.76 & & \\
\hline T P. sicana & & 14.8 & & 800.20 & 910.76 & & \\
\hline В O. universa & & 15.1 & & 808.39 & 910.76 & & \\
\hline T H. altiaperta & 15.6 & & & 857.50 & 1058.06 & & \\
\hline B $P$. sicana & & 16.4 & & 910.25 & 1089.72 & & \\
\hline $\mathrm{T} C$. dissimilis & & 17.3 & & 925.35 & 1089.72 & & \\
\hline T S. belemnos & 18.3 & & & 967.44 & 1108.08 & & \\
\hline B G. insueta & & 18.8 & & 973.41 & 1140.00 & & \\
\hline B S. belemnos & 19.2 & & & 1003.04 & 1171.86 & & \\
\hline B G. altiapertura & & 20.5 & & 1086.75 & 1204.13 & & \\
\hline T G. kugleri & & 21.5 & & 1099.62 & 1204.13 & & \\
\hline B D. druggii & 23.2 & & & 1117.85 & 1242.52 & & \\
\hline
\end{tabular}

the sedimentary and stratigraphic record, and the sequence boundaries can be clearly identified on these data (back-pocket foldout). Consequently, the logging data may also be used to make lithologic and sequence stratigraphic interpretations in gaps of core recovery.

\section{Stratigraphic Response of Carbonates to Sea-Level Changes}

Overall core recovery was sufficient $(55.3 \%)$ to document the facies successions throughout the cores (Fig. 3; back-pocket foldout). The facies successions contain indications of sea-level changes on two different scales. First, there are high-frequency alternations of layers containing more platform-derived material with layers consisting of more pelagic sediments. In the Pleistocene and Pliocene periplatform section, these alternations are reflected in the ratio between neritic components and nannofossils and mineralogically between aragonite and low-magnesium calcite (LMC). In previous studies, these cycles have been shown to correlate to the orbitally forced, high-frequency, sea-level changes in the Quaternary (Droxler et al., 1983). We found similar decimeter- to meter-scale, high-frequency changes in facies of the Miocene sections in all the holes. The Miocene cycles display decimeter-thick alternations of light-colored, bioturbated, well-cemented biowackestones and less cemented, darker biowackestones with compacted burrows (Fig. 7). The Miocene alternations are interpreted to reflect changes in the rate of neritic input (metastable aragonite and high-magnesium calcite [HMC]). Thus, the well-cemented wackestones represent higher neritic input and have a greater potential for diagenetic alteration than the less-cemented intervals with less neritic input. As a result of the color changes and the cementation differences associated with these alterations, these cycles are also recorded in the color reflectance and in the wireline log data. In particular, the Formation MicroScanner data provided a continuous record of these cycles at three sites (Sites 1003, 1005, and 1006). Shore-based analyses will determine the frequency of these cycles in the Miocene.

A repetitive pattern of facies succession on the order of tens to hundreds of meters thickness documents a sedimentary record of longer-term sea-level changes. These larger-scale patterns are imaged in the seismic sequences. Similarly, as in the small-scale cycles, 


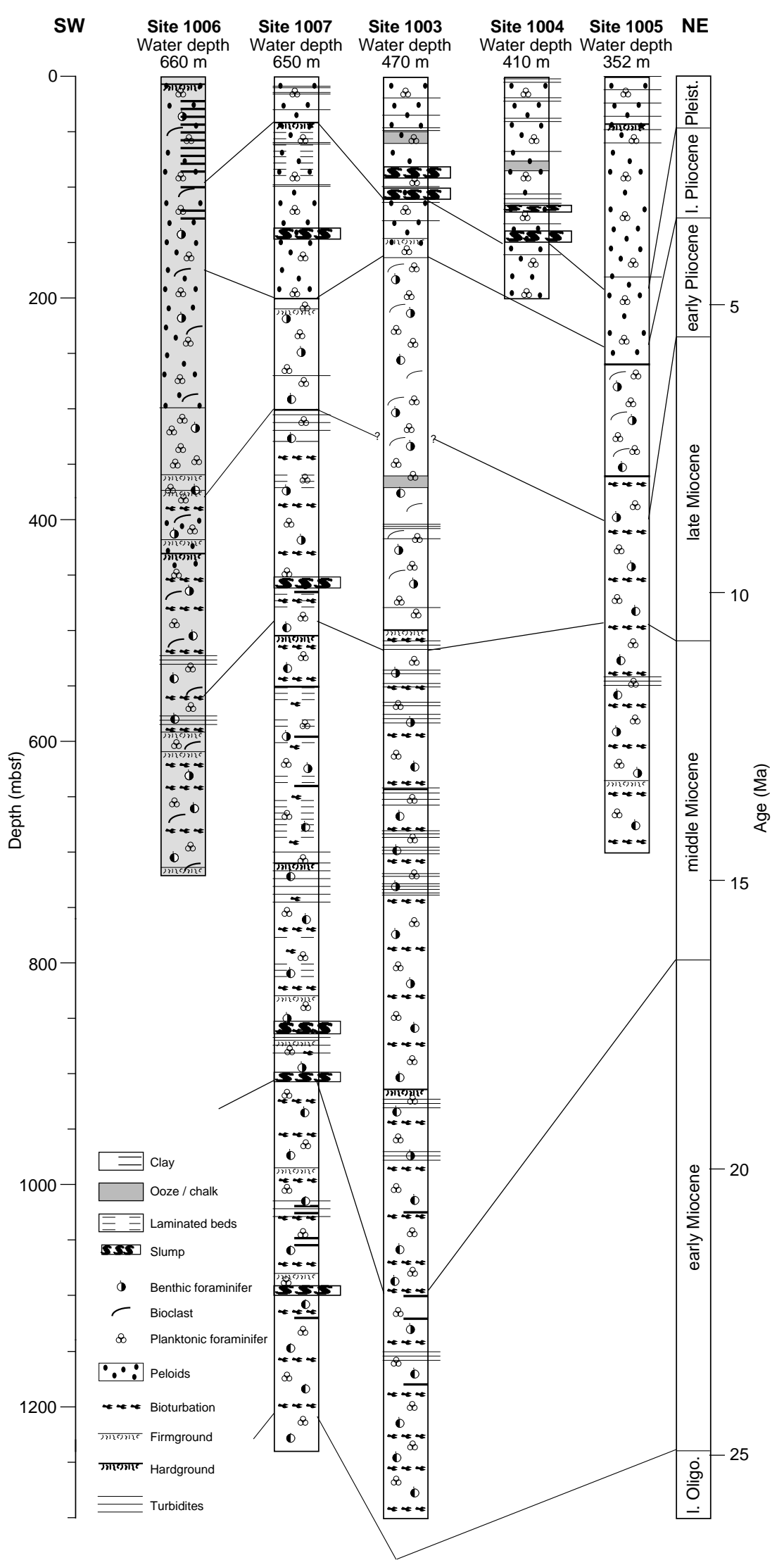

Figure 3. Lithostratigraphic summary of Leg 166 Bahamas Transect Sites 1003-1007 (Sites 1008 and 1009 drilled 100 km to the south are not shown). An enlarged, more detailed version of the lithostratigraphic columns is in the back-pocket foldout. 


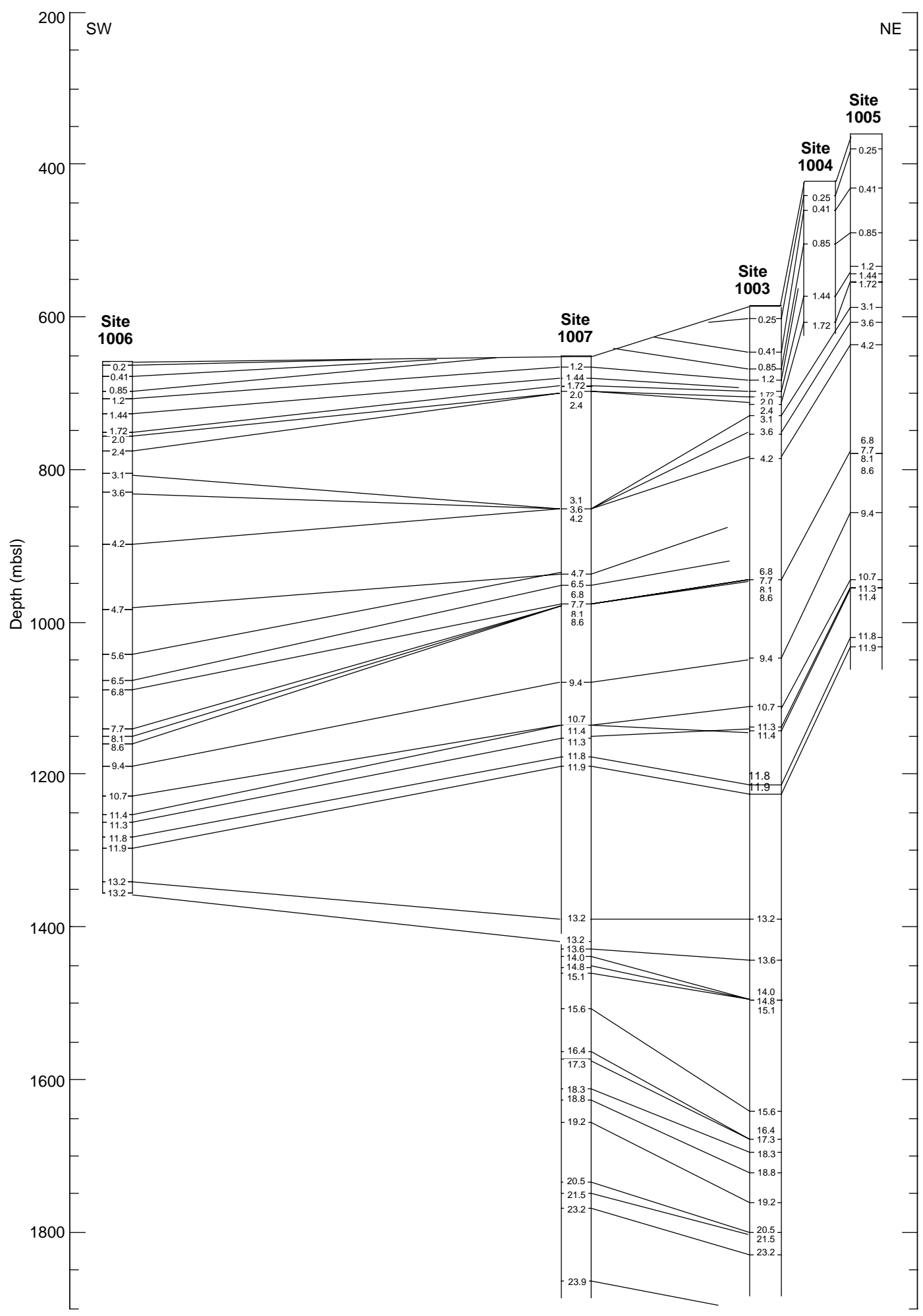

Figure 4. Age-correlation diagram of the Leg 166 Bahamas Transect Sites 1003-1007 (Sites 1008 and 1009 drilled 100 km to the south are not shown).

changes in the amount of platform-derived material indicate periods of high and low sea level. Platform exposure during low sea level is reflected in reduced sedimentation rates, occasionally leading to submarine hardground formation on the slope. In addition, erosion of the platform margin during these periods is documented by the deposition of coarse-grained packstones and floatstones in pelagic-rich background sediments. Erosional truncation is also observed in the proximal slope sites, which leads to hiatuses in the biostratigraphic successions (Fig. 5). High-frequency cycles are best developed during sea-level rises and usually compose the middle part of the sequences. Redeposition of platform carbonates occurs again in the upper portion of the sequences. This pattern is best developed in the Mi- 

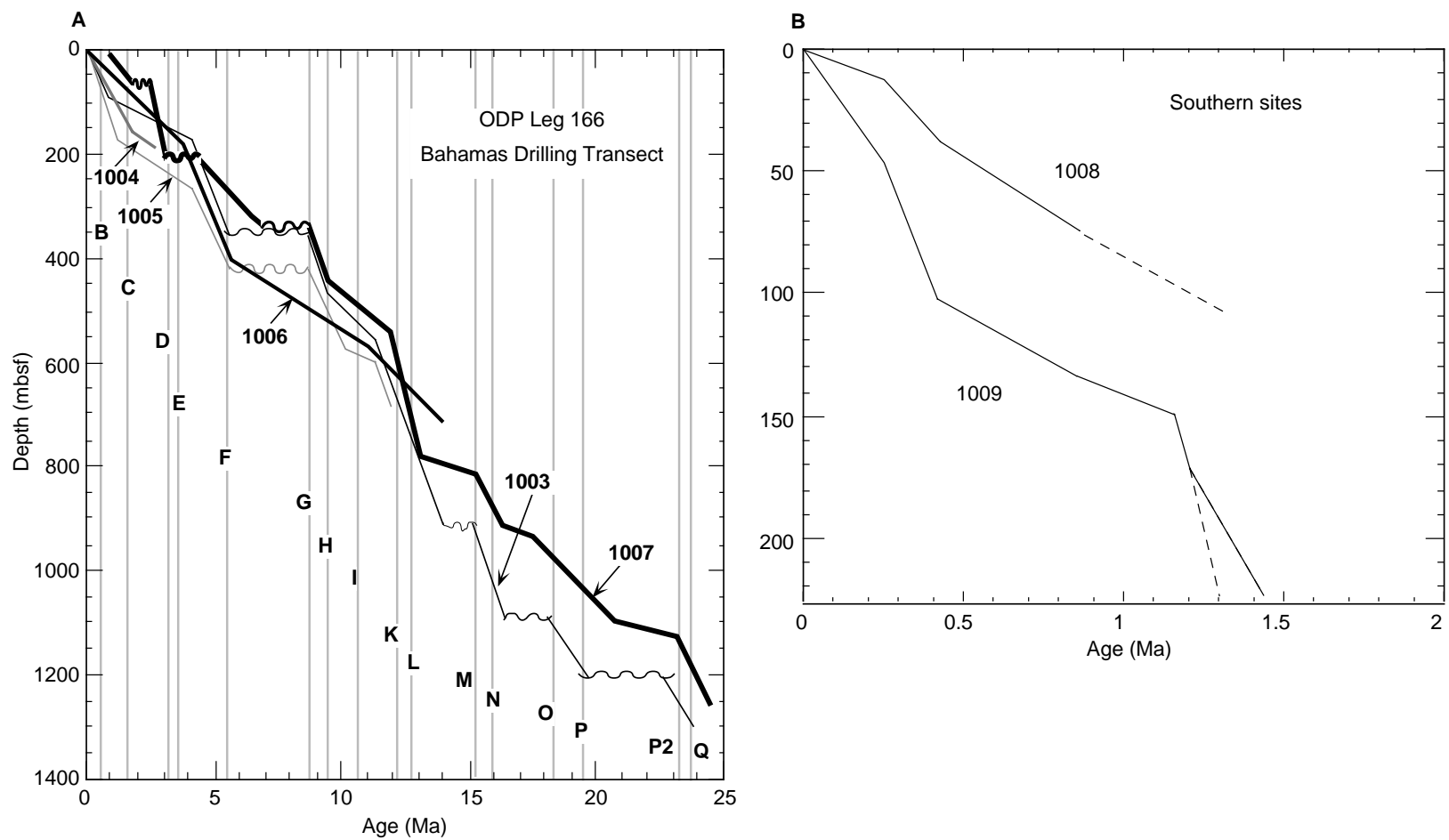

Figure 5. Summary of sedimentation rates for Leg 166 sites. A. The proximal Sites 1003 and 1005 display several hiatuses that are equivalent to times of low sedimentation rate in the more distal Site 1007. Data were obtained from both calcareous nannofossils and planktonic foraminifers. B. Sedimentation rates of the southern Sites 1008 and 1009. High sedimentation rates indicate an increase of platform-derived material during highstands of sea level.

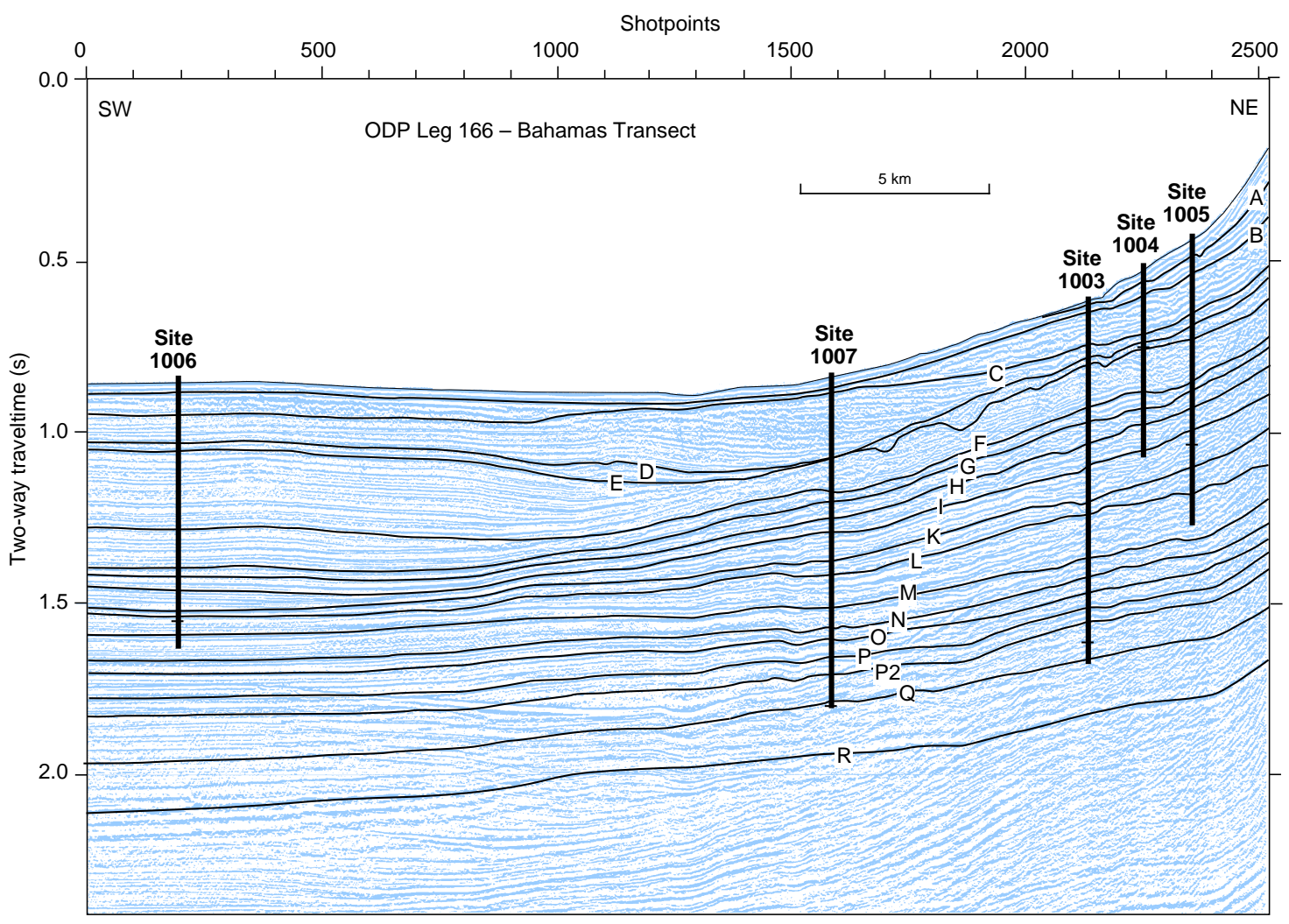

Figure 6. Seismic line showing the prograding sequences at the western margin of the GBB with the locations of the Bahamas Transect drilled during Leg 166. Seismic sequence boundaries (SSBs) were labeled A-I, K-R. A SSB between P and Q was recognized during the cruise and was labeled P2. SSB R was not penetrated during Leg 166. An enlarged version of this profile is shown in the back-pocket foldout. 


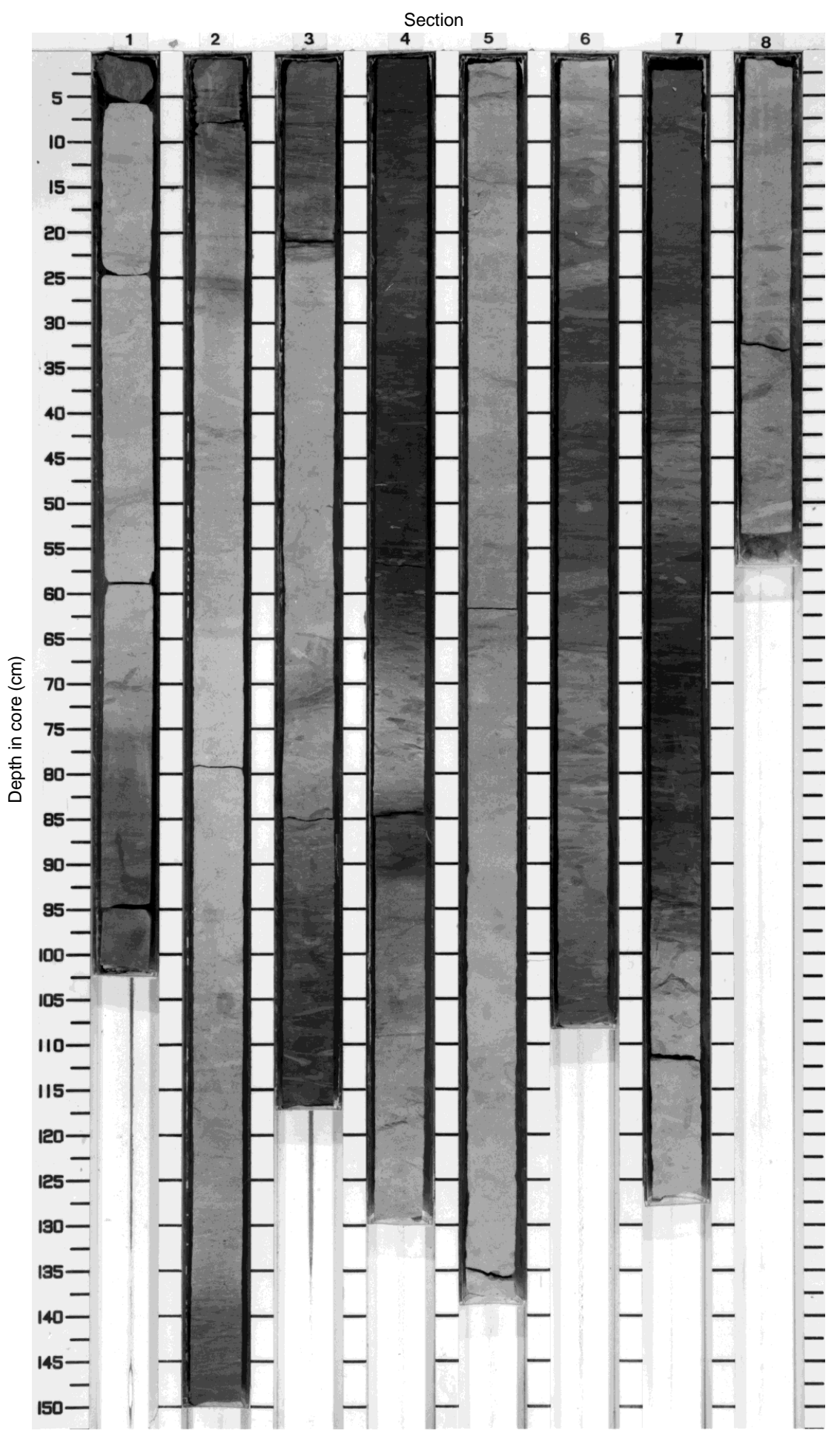

Figure 7. Core 166-1003C-67R displaying typical Miocene cyclic alternation of dark and light bioturbated biowackestones. Open burrows occur in the light-colored, well-cemented layers, whereas the burrows in the darker-colored, clay-bearing, less well-cemented layers are flattened. Interval spans 1088.5 to 1098.1 mbsf.

ocene age sediments when the platform had a ramp-like morphology. In the Pliocene and Pleistocene, the bulk of the sediments, especially in the more proximal locations, are dominated by thick successions of fine-grained material, but turbidites occur preferentially in the upper portions of the sequences. More mass-gravity flow deposits are found in the toe-of-slope site (Site 1007), indicating that the steep upper slopes are bypassed by these flows.
To complement the cores and fill in recovery gaps, an extensive logging program was implemented in the four deep transect holes. At Site 1003, a dedicated logging hole was drilled when hole conditions prevented the logging of the cored hole. The acquired logs provide detailed information on the petrophysical and sedimentary properties and structure of the strata. Log-to-core correlation permits significant interpretations about variations in sedimentation patterns along the 
transect sites of GBB from the earliest early Miocene to the Holocene (back-pocket foldout). The general compatibility of the discrete data points from shipboard petrophysical measurements with the log data supports the integrity of the data sets. These logging data will help to correlate the seismic sequence boundaries to the cores. Over $3 \mathrm{~km}$ of Formation MicroScanner data were acquired, which will allow us to analyze the small-scale cycles observed in the cores and assess the frequency of orbitally driven climate and sea-level changes in the Miocene.

\section{Sequence Stratigraphy}

Sequence analysis was performed on the seismic data prior to drilling (Fig. 6). Erosional truncation and onlap geometries were used to identify seismic sequence boundaries. These geometrical relationships were best observed farther east along the buried platform margins below the modern Great Bahama Bank (Fig. 2; Eberli et al., this volume). The reflections identified as sequence boundaries were traced to the slope and basinal areas of the Leg 166 Bahamas Transect sites. Tracing the reflection horizons is straightforward for the Pleistocene and the lower and middle Miocene sequences. Uncertainties exist for the upper Miocene and lower Pliocene sequence boundaries because the multiple reflections and diffractions generated by the steep GBB margin could not be completely removed. We identified 17 sequences in the Neogene section, which we labeled $a-i$ and $k-q$, with the respective basal seismic sequence boundaries labeled A-I and $\mathrm{K}-\mathrm{Q}$. Most of the sequence boundaries are conformable at the Leg 166 sites; however, truncation is observed at the more proximal sites. By reaching the Oligocene at Site 1007, a complete record for the sequence stratigraphic architecture is in hand for the entire Neogene.

For an accurate tie of the core depths to the seismic data, vertical seismic profiles with the Well Seismic Tool were acquired in each of the deep holes (see individual site chapters in this volume). These check-shots allowed us to calculate an accurate time to depth conversion of the seismic reflections. These experiments proved to be extremely valuable as neither the integrated sonic log velocity nor the shipboard velocity measurements provided an accurate velocity profile in all the holes. In some cases, errors of up to $50 \mathrm{~m}$ were obtained using solely the logs and discrete shipboard velocity measurements. Most seismic sequence boundaries coincide, within a seismic resolution of about $10 \mathrm{~m}$, with a lithologic facies change indicative of a sealevel change (back-pocket foldout).

\section{Timing of Sequence Boundaries}

A crucial task was to establish the ages of the seismic sequence boundaries and the sea-level changes associated with them. Calcareous nannofossils and planktonic foraminiferal biostratigraphic datums were used to establish an age-depth relationship for each of the sites drilled as part of the Bahamas Transect (Sites 1003-1007) (Table 1; Fig. 5). Many biohorizons from both groups were identified, establishing a framework for intersite correlation, which was transferred into time using the geomagnetic polarity time scale of Berggren et al. (1995) (back-pocket foldout; "Explanatory Notes" chapter, this volume). The latter step allowed us to test the age consistency of the sequence boundaries observed in the seismic records as well as in the logging data combined with lithologic changes observed in the recovered sedimentary section. The overall consistency in the relative position of planktonic foraminiferal and nannofossil datums means that a reliable framework for intersite correlation was established for the Bahamas Transect sites (Fig. 4).

Biostratigraphic dating of the sediments in upper slope carbonate environments was not an easy task. At the Leg 166 sites, calcareous microfossils were very rare and sometimes difficult to identify due to dilution and poor preservation. In addition, low remanent magnetization of these carbonates prevented the construction of a magnetostratigraphy using shipboard measurements. The biostratigraphy for these holes was established by using the core-catcher samples in the Pleistocene to upper Pliocene sections, and samples from discrete clayey layers in the Miocene sections, which contained moderately preserved calcareous microfossils. We anticipate further refinement of the age models after detailed shore-based analyses of samples.

Site 1006, located in a distal position from the platform in the Straits of Florida is less affected by diagenesis and erosion associated with sea-level falls than those sites drilled on the upper slope (Figs. $4,5)$. This site, with nearly continuous sedimentation, provides a benchmark for establishing the stratigraphic order of the marker species in this region. Most conventional nannofossil and planktonic foraminiferal biohorizons were found in the Pleistocene to middle Miocene interval. Nannofossil biostratigraphic datums were used exclusively to characterize sedimentation in the Pleistocene section of this site, whereas the Pliocene and Miocene sections were constrained by both planktonic foraminiferal and nannofossil events.

The depths of planktonic foraminiferal and nannofossil datum levels at Site 1006 were consistent with the relative order of these events in tropical regions except for a few cases. One important mismatch were the first occurrences of Globigerinoides conglobatus and Globorotalia margaritae relative to nannofossil events in the same interval (Table 1; back-pocket foldout). These datums have been assigned ages of 5.7 Ma (Berggren et al., 1985) and 6.4 Ma (Berggren et al., 1995), respectively. Chaisson and Pearson (in press) have subsequently modified the age of $G$. conglobatus to be $6.2 \mathrm{Ma}$ in the tropical Atlantic. In either case, both of these events occur below the top of the small Reticulofenestra spp. interval at Site 1006, dated as 6.5 Ma (Sato et al., 1991). This relationship was also observed at Site 1007. Using the nannofossils only in the uppermost Miocene section of Site 1006 to establish the age-depth relationship, indicates that the first occurrences of $G$. conglobatus and $G$. margaritae in the Bahamian region are $6.8 \mathrm{Ma}$ and $7.0 \mathrm{Ma}$, respectively. The base of $G$. conglobatus became an important datum level to identify an upper Miocene hiatus in the upper slope Sites 1003 to 1005, and 1007 (see below).

A second apparent problem in the order of the biostratigraphic datums occurred near the middle/upper Miocene boundary. In tropical settings, the first appearance of Catinaster coalitus (11.3 Ma) occurs above the last appearance of Globorotalia mayeri (11.4 Ma; Berggren et al., 1995). At Sites 1003 through 1007, G. mayeri is recorded at the same level or above the $C$. coalitus level. However, it has been shown that the top of the G. mayeri interval is slightly younger in subtropical regions (Gulf of Mexico, Jamaica, and North Atlantic Site 563) than observed in the tropics (Miller et al., 1994; Zhang et al., 1993). The position of G. mayeri relative to C. coalitus at the Bahamas Transect sites is consistent with this observation.

A third inconsistency in the relative position of the datums involves the first occurrence of Cyclicargolithus floridanus (13.2 Ma), with respect to the first occurrence of Globorotalia fohsi (12.7 Ma). At Site 1003, the base of C. floridanus is above G. fohsi but occurs at the top of a slumped interval.

In contrast to Site 1006, unconformities appear in the upper slope Sites 1003 through 1005 (Figs. 4-6). The most prominent of these is a hiatus in the late Miocene, which was recognized at all slope sites by the juxtaposition of $G$. conglobatus (last appearance datum [LAD]) at $6.8 \mathrm{Ma}$ ) with Discoaster hamatus (LAD at 8.7 Ma). Also observed at this level was the first appearance of Globorotalia cibaoensis (7.7 Ma) and Globigerinoides extremus (8.1 Ma). At Site 1007, the upper part of the small Reticulofenestra spp. interval (LAD at $6.5 \mathrm{Ma}$ ) was found above the unconformity, indicating the presence of uppermost Miocene sediments (Messinian). Furthermore, the $16-\mathrm{m}$ interval above the $6.5 \mathrm{Ma}$ level contains poorly preserved nannofossils. Above this zone of uncertainty, the sediments are younger than $4.7 \mathrm{Ma}$, based on the first appearance of Ceratolithus rugosus. It is unclear whether this is the true first appearance or whether it extends farther down. Therefore, the interval of poor preservation represents either an interval of very low sedimentation $(<1 \mathrm{~cm} / \mathrm{k} . \mathrm{y}$.) or contains a hiatus that straddles the Miocene/Pliocene boundary. A 
lithologic break at the base of this interval of poor preservation indicates the presence of a hiatus. At Sites 1003 and 1005, a similar interval of very poor preservation was also found, but it extended well above the unconformity, preventing any age assignment to this interval.

At Site 1007, positioned at the toe-of-slope, three erosional surfaces were observed in the Pliocene-Pleistocene section (Fig. 4). The first, at the seafloor, is a modern erosional surface with the uppermost sediments being older than $0.95 \mathrm{Ma}$. Within the upper Pliocene, an erosional surface is identified based on the co-occurrence of several planktonic foraminiferal events (2.0 to $2.4 \mathrm{Ma})$. The lower/upper Pliocene boundary is unconformable, based on the juxtaposition of the first appearance of Globorotalia tosaensis (3.2 Ma) and Globigerina nepenthes (4.2 Ma). These unconformities bound an extensive upper Pliocene toe-of-slope and drift deposit not observed at the other sites (Figs. 4, 6).

Sites 1003 and 1007 recovered middle and lower Miocene sequences, showing four cycles of alternating sedimentation rates. At both sites, periods of faster deposition ( $>5 \mathrm{~cm} / \mathrm{k} . \mathrm{y}$.) occurred from 11.5 to $13 \mathrm{Ma}, 15$ to $16.5 \mathrm{Ma}, 17.5$ to $20.5 \mathrm{Ma}$, and older than $23 \mathrm{Ma}$. At Site 1007 , slow but continuous pelagic sedimentation $(<2 \mathrm{~cm} / \mathrm{k} . \mathrm{y}$.) occurred from 9.5 to $11.5 \mathrm{Ma}, 13$ to $15 \mathrm{Ma}, 16.5$ to $17.5 \mathrm{Ma}$, and 20.5 to $23 \mathrm{Ma}$. In contrast, these intervals of reduced sedimentation are represented by hiatuses at Site 1003 .

The overall consistency in the relative position of planktonic foraminiferal and nannofossil datums means that a reliable framework for intersite correlation was established for the Bahamas Transect sites. Using the biostratigraphic framework, we tentatively estimated the ages of the 17 seismic sequence boundaries (SSB) (Table 2). The age at the correlative depth of the SSB was calculated using biostratigraphic datums and extrapolating sedimentation rates between datums (Fig. 8; Table 2). Although this procedure carries the uncertainty of both the exact position of the biostratigraphic datums and the seismic resolution, the sequence boundaries showed consistent ages along the seismic reflections (Fig. 8). This result is exciting as it confirms one of the major assumptions of sequence stratigraphy that seismic reflections are time lines. On the slope sites, several of these sequence boundaries coincide with biostratigraphically detected hiatuses indicating erosion or nondeposition (Figs. 5, 8). In some cases, erosional downcutting on the slope is also indicated by slightly older ages of the SSBs compared to their ages in the distal areas. Therefore, to determine the ages of the sea-level changes, the ages of the SSBs were taken at the conformable portion of the sequences (Fig. 7; Table 2 ). The preliminary ages of the SSBs are estimated as: $0.1,0.6,1.7$, 3.1, 3.6, 5.4, 8.7, 9.4, 10.7, 12.2, 12.7, 15.1, 15.9, 18.3, 19.4, 23.2, and 23.7 Ma. A comparison of seismic sequences with the global sea- level curve (Haq et al., 1987) indicates that nearly all major (third-order) sea-level changes are recorded along the Bahamas Transect. The ages of the sequence boundaries probably have an error bar of approximately $0.2-0.5 \mathrm{~m} . \mathrm{y}$, given the seismic resolution and the relatively coarse shipboard biostratigraphic sampling. Shore-based analyses of oxygen and strontium isotopic records, together with an integrated analyses of sediment facies, biostratigraphy, wireline log patterns, and seismic reflection data will enable a refinement of the age model as well as a precise subsidence analysis. The database acquired during Leg 166, together with the Bahamas Drilling Project data set, will allow for accurate estimates of the magnitude and rate of sea-level changes during the Neogene.

\section{Low-Latitude, Neogene Stable Isotopic Signals}

At Site 1006, the distal site of the Bahamas Transect, we anticipated retrieving low-latitude isotopic signals of the Ice House World in the Neogene and Quaternary. Site 1006 revealed the presence of most conventional nannofossil and planktonic foraminifers in the middle Miocene to Pleistocene section. In addition, recovery was excellent and the preservation of the foraminifers was good throughout. Hence, all the prerequisites are in hand to establish an oxygen isotopic record of sea-level changes in the Bahamas Transect. The correlation of the sedimentary and the isotopic record will enable us to assess the causal relationship between sea-level changes and the sequence stratigraphic pattern, thereby fulfilling the third major objective within the sea-level theme of Leg 166. Furthermore, the expanded Pliocene and upper Miocene sequences at Site 1006, combined with the excellent preservation, will likely make this a classic site for upper Neogene paleoceanography in the low-latitude Atlantic. In addition, changes in the sediment composition are postulated to fluctuate in conjunction with variations in the strength of the Florida Current. We should be able to correlate these variations with changes in sea level as recorded by the prograding and regressive sequences at platform sites and by the oxygen isotopic signature of the foraminifers.

\section{FLUID CIRCULATION IN A CARBONATE PLATFORM}

To assess the processes responsible for fluid circulation in the GBB, we made an extensive set of in situ temperature and pore-water chemistry analyses along two transects across the western slope of the GBB. The association of the fluid chemistry and heat-flow sampling program with the sea-level objectives means that changes in

Table 2. Tentative age assignments of seismic sequence boundaries.

\begin{tabular}{|c|c|c|c|c|c|c|c|c|}
\hline SSB & $\begin{array}{l}\text { Site } 1005 \\
\text { (Ma) }\end{array}$ & $\begin{array}{l}\text { Site } 1004 \\
\text { (Ma) }\end{array}$ & $\begin{array}{l}\text { Site } 1003 \\
\quad(\mathrm{Ma})\end{array}$ & $\begin{array}{l}\text { Site } 1007 \\
\text { (Ma) }\end{array}$ & $\begin{array}{l}\text { Site } 1006 \\
\text { (Ma) }\end{array}$ & $\begin{array}{l}\text { Estimated SSB } \\
\text { age (Ma) }\end{array}$ & Series/Epoch & Stage \\
\hline A & 0.1 & 0.16 & 0.09 & & & 0.1 & Holocene/Pleistocene(?) & Holocene/Pleistocene \\
\hline B & 0.6 & 0.73 & 0.25 & & & 0.6 & Pleistocene & Pleistocene \\
\hline $\mathrm{C}$ & 1.6 & 1.7 & $1.2-1.6$ & $1.5-1.7$ & 1.8 & 1.7 & Pleistocene/Pliocene & earliest Pleistocene \\
\hline $\mathrm{D}$ & 2.9 & 2.6 & 3.1 & $3.2-4.2$ & 3.1 & 3.1 & late/early Pliocene & late Pliocene \\
\hline $\mathrm{E}$ & 3.6 & & 3.8 & $3.2-4.2$ & 3.6 & 3.6 & late early Pliocene & early/late Pliocene \\
\hline $\mathrm{F}$ & 6 & & 5.6 & $5.5-6.4$ & 5.4 & 5.4 & late Miocene & Messinian \\
\hline G & $6.2-8.8$ & & $6.2-8.7$ & 8.8 & 8.7 & 8.7 & late Miocene & Tortonian \\
\hline $\mathrm{H}$ & 9.3 & & 9 & 9.4 & 9.4 & 9.4 & late Miocene & Tortonian \\
\hline I & 10.2 & & 10.6 & $10.9-11.4$ & 10.7 & 10.7 & late/middle Miocene & Tortonian \\
\hline $\mathrm{K}$ & & & 12.2 & 12.2 & 12.4 & 12.2 & middle Miocene & Seravallian \\
\hline $\mathrm{L}$ & & & 12.7 & 12.5 & 12.7 & 12.7 & middle Miocene & Seravallian \\
\hline M & & & $13.6-15.1$ & 15.1 & & 15.1 & middle Miocene & Langhian \\
\hline $\mathrm{N}$ & & & 15.9 & $16.2-16.4$ & & 15.9 & middle Miocene & Langhian \\
\hline $\mathrm{O}$ & & & 18.4 & 18.2 & & 18.3 & early Miocene & Burdigalian \\
\hline $\mathrm{P}$ & & & 19.2 & 19.4 & & 19.4 & early Miocene & Burdigalian \\
\hline P2 & & & $19.4-22.5$ & 23.2 & & 23.2 & early Miocene & Aquitanian \\
\hline \multirow[t]{2}{*}{ Q } & & & & 23.7 & & 23.7 & early Miocene & Aquitanian \\
\hline & & & & & & & Oligocene & Chattian \\
\hline
\end{tabular}

Note: SSB = seismic sequence boundary. 


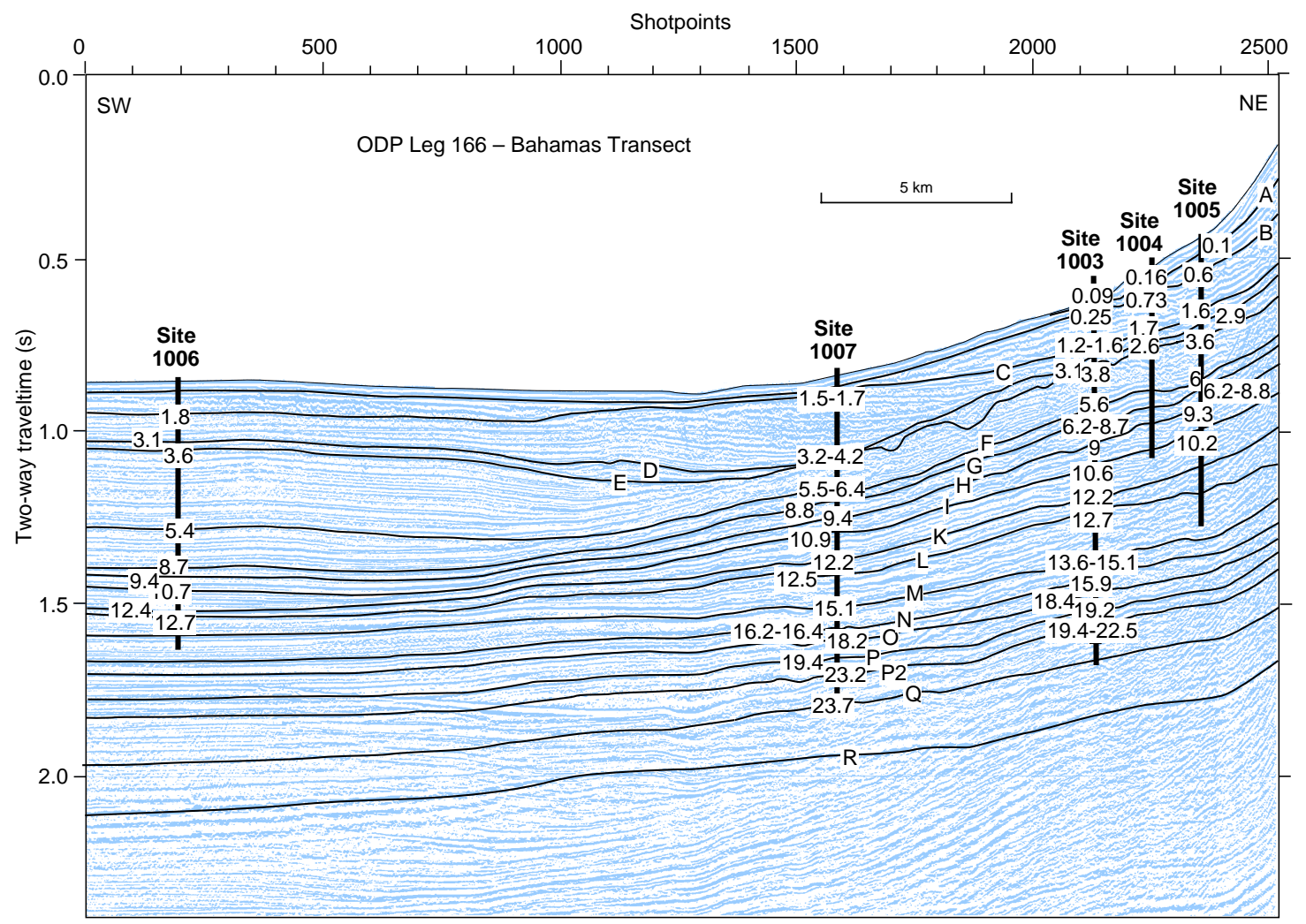

Figure 8. Same seismic line as in Figure 6 with ages of sequence boundaries calculated using biostratigraphic datums and extrapolating sedimentation rates between datums. Despite the uncertainty of both the exact position of the biostratigraphic datums and the seismic resolution, the sequence boundaries show consistent ages along the seismic reflections.

fluid chemistry were examined not only as a function of age and depth, but also within a sequence stratigraphic framework. Therefore, this approach was fundamentally different from other investigations of pore-water profiles along carbonate platforms that in most instances only drilled single holes.

The clearest evidence for active recharge of fluids through the margin of GBB is derived from the nonsteady state profiles of both conservative and nonconservative elements in the pore-water profiles within the upper $100 \mathrm{~m}$ obtained from both the northern (Sites 10031007) and southern transects (Sites 1008-1009). A zone was identified (the "flushed zone") that is confined to the upper $40 \mathrm{mbsf}$ in which there is an absence of geochemical gradients (Figs. 8, 9). The geochemical data in this interval show essentially no change from bottom seawater concentrations for all of the normally measured cations and anions. The flushed zone at Sites 1006 and 1007, which are situated farther from the platform, is reduced in thickness and exhibits small, but nevertheless significant, increases in $\mathrm{Sr}^{2+}$. This suggests a less active flushing mechanism at these sites. A similar upper flushed zone, approximately $40 \mathrm{~m}$ thick, also is observed at the sites drilled along the more southerly transect. Most of the sites also showed nonsteady state irregular temperature profiles in this part of the sedimentary column. The absence of geochemical gradients and the irregular temperature profiles support the notion that there is advection of seawater through this portion of the sedimentary column. The small increases in $\mathrm{Sr}^{2+}$ at the more distal sites indicate that fluid flow here is reduced relative to the proximal sites.

Below the flushed zone, there is a sharp change in the concentrations of both conservative and nonconservative elements. The $\mathrm{SO}_{4}{ }^{2-}$ concentration decreases sharply, whereas alkalinity and $\mathrm{Sr}^{2+}$ increase. The nature of these gradients is nonsteady state and reflects the presence of a downward-advecting fluid. An unexpected finding at all

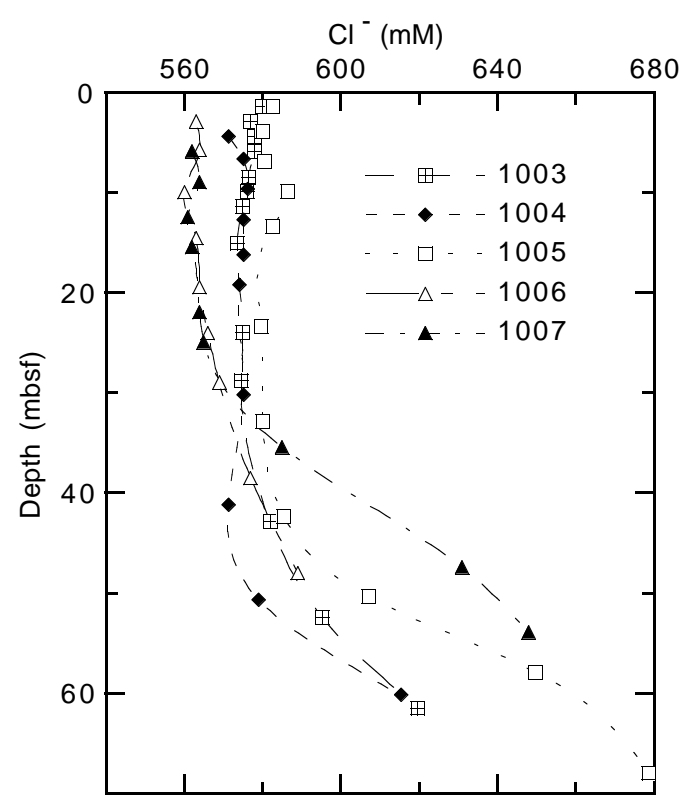

Figure 9. Interstitial water profiles from Leg 166 sites illustrating downhole changes in $\mathrm{Cl}^{-}$. Note the uniform concentration of $\mathrm{Cl}^{-}$in the upper $40 \mathrm{~m}$ of all holes suggesting the presence of a well flushed zone. 


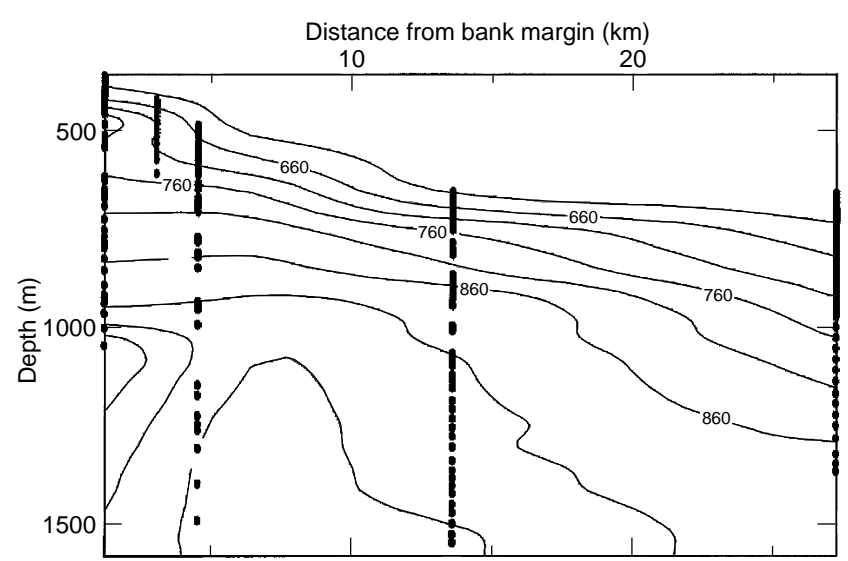

Figure 10. Contour map of the pore-water $\mathrm{Cl}^{-}$concentrations along the Leg 166 sites of the Bahamas Transect. Note the uniform concentration in the upper portion of the profile.

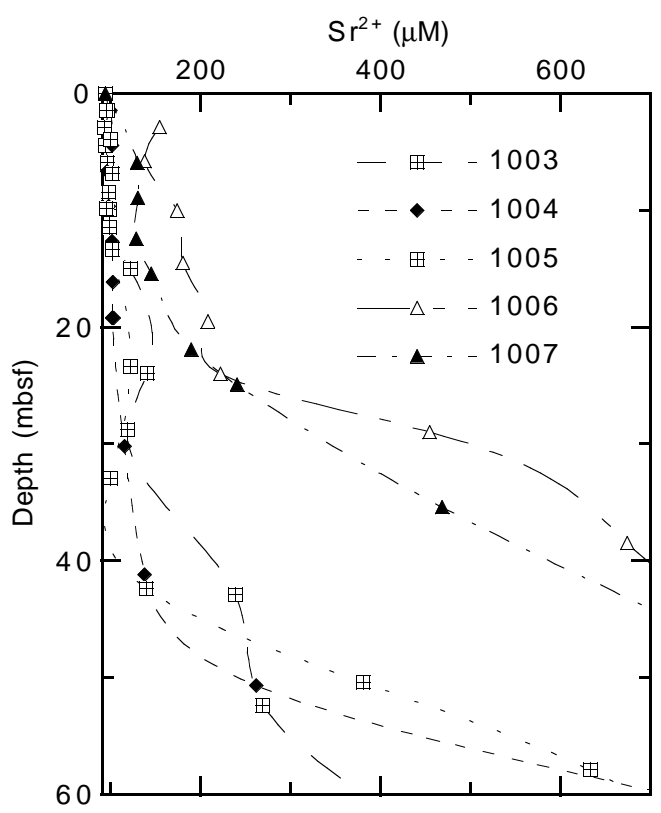

Figure 11. Interstitial water profiles from Leg 166 sites illustrating downhole changes in $\mathrm{Sr}^{2+}$. The upper $40 \mathrm{~m}$ at Sites 1003-1005 show minimal changes in the $\mathrm{Sr}^{2+}$ concentration suggesting the active advection of pore water through the sediments. Sites 1006 and 1007 show a similar pattern but the levels are slightly elevated and the zone is thinner.

sites was the increase in $\mathrm{Cl}^{-}$concentration with increasing depth. This increase is probably a result of the diffusion of $\mathrm{Cl}^{-}$and $\mathrm{Na}^{+}$from an underlying brine or evaporite deposits (Fig. 10).

Within the overall diffusive profiles of conservative elements such as $\mathrm{Cl}^{-}$, there are small perturbations. These changes are in excess of the analytical error and cannot be attributed to contamination. The best example of these variations occurs at Site 1007, where they are associated with changes in physical properties. Initial interpretation suggests these changes may reflect lateral movement of fluids along sequence boundaries.
Based on the data gathered at the seven sites drilled during Leg 166 , there is clear evidence that a mechanism exists that produces active exchange between the upper $40 \mathrm{~m}$ of sediments and the bottom waters. We propose that the absence of geochemical gradients and the irregular temperature profiles are a result of advection of seawater through this portion of the sedimentary column. Below the flushed zone, the nonsteady concentration profiles of both conservative and nonconservative elements (e.g., $\mathrm{SO}_{4}{ }^{2-}$ and $\mathrm{Sr}^{2+}$ ) probably reflect depression by a downward advecting fluid. The overall pattern of diffusion and fluid movement can be best seen in the $\mathrm{Cl}^{-}$contour crosssection using Sites 1003-1007 (Fig. 11). In this figure the upper mixed zone is shown as a thin homogeneous layer extending from Site 1005 to Site 1006. At the proximal sites (1003-1005) there appears to be fluid entering the platform as a tongue of less saline water underlying a more $\mathrm{Cl}^{-}$rich one. With increasing depth at all sites there is a strong diffusional gradient from an underlying $\mathrm{Cl}^{-}$rich brine.

At the present time we do not know the precise mechanism involved in the flushing in the upper portions of the sections, only that it exists. However, the observations are consistent with water being drawn into the platform by Kohout convection (Kohout, 1967). In this mechanism the temperature difference between the platform interior and the adjacent seaways causes underpressure to develop within the platform, which then draws water through the flanks of the platform.

\section{REFERENCES}

Berggren, W.A., Kent, D.V., Swisher, C.C.S. III, and Aubry, M.P., 1995. A revised Cenozoic geochronology and chronostratigraphy. In Berggren, W.A., Kent, D.V., and Hardenbol, J. (Eds.), Geochronology, Time Scales and Global Stratigraphic Correlations: A Unified Temporal Framework for an Historical Geology, Soc. Econ. Paleont. Min. Special Volume, 54:129-212.

Berggren, W.A., Kent., D.V., and Van Couvering, J.A., 1985. The Neogene; part 2. Neogene geochronology and chronostratigraphy. In Snelling, N.J. (Ed.), The Chronology of the Geological Record. Geol. Soc. London Mem., 10:211-260.

Chaisson, W.P., and Pearson, P.N., in press. Planktonic foraminifer biostratigraphy at Site 925, western tropical Atlantic: the last 12 m.y. In Curry, W.B., Shackleton, N.J., Richter, C., Bralower, T.J. (Eds.), Proc. ODP, Sci. Results, 154: College Station (Ocean Drilling Program).

Droxler, A.W., Schlager, W., and Whallon, C.C., 1983. Quaternary aragonite cycles and oxygen-isotope record in Bahamian carbonate ooze. Geology, 11:235-239.

Eberli, G.P., Kendall, C.G.St., Moore, P., Whittle, G.L., and Cannon, R., 1994. Testing a seismic interpretation of the Great Bahama Bank with a computer simulation. AAPG Bull., 78:981-1004.

Haq, B.U., Hardenbol, J., and Vail, P.R., 1987. Chronology of fluctuating sea levels since the Triassic. Science, 235:1156-1167.

Kohout, F.A., 1967. Ground-water flow and the geothermal regime of the Floridian Plateau. Trans. Gulf Coast Assoc. Geol. Soc., 17:339-354.

Miller, K.G., Wright, J.D., van Fossen, M.C., and Kent, D.V., 1994. Miocene stable isotopic stratigraphy and magnetostratigraphy of Buff Bay Jamaica. Geol. Soc. Am. Bull., 106:1605-1620.

Sato, T., Kameo, K., and Takayama, T., 1991. Coccolith biostratigraphy of the Arabian Sea. In Prell, W.L., Niitsuma, N., et al., Proc. ODP, Sci. Results, 117: College Station, TX (Ocean Drilling Program), 37-54.

Zhang, J., Miller, K.G., and Berggren, W.A., 1993. Neogene planktonic foraminiferal biostratigraphy of the northeastern Gulf of Mexico. Micropaleontology, 39:299-326.

Ms 166IR-102 